\title{
Do grafite aos murais e de volta outra vez: a paisagem urbana espetacular de Filadélfia
}

\author{
JAMES DICKINSON (TEXTO E FOTOS)
}

\section{Resumo}

A paisagem urbana contemporânea de Filadélfia é extremamente variada e colorida, com milhares de murais e de grafites municipais competindo por atenção nas paredes da cidade. Este é o resultado de uma contestação de longa data entre uma vigorosa tradição da arte de rua de natureza transgressiva e um ambicioso programa municipal destinado a controlar o espaço visual urbano através de uma arte pública oficialmente legitimada e patrocinada. Neste ensaio o papel de Filadélfia como um centro de inovação do grafite é discutido, tal como o são as Rede Anti-Graffiti existentes e o Programa de Arte Mural que visam conter o fenômeno do grafite por intermédio da produção de murais cívicos. Outros processos de embelezamento dos bairros através da arte pública, bem como as novas formas de arte de rua ilícitas, tais como cartazes e stencil, também serão abordadas.

Palavras-chave: Paisagem urbana, arte pública, grafite
Figure 1

Ben Jammin' (GET UP ART). A stencil portrait of iconic Philadelphian, founding American and polymath, Benjamin Franklin, with modern day boom-box 


\section{From graffiti to murals and back again: \\ Philadelphia's spectacular streetscape}

JAMES DICKINSON (TEXT AND PHOTOS)

\section{Abstract}

Philadelphia's contemporary streetscape is remarkably varied and colorful with thousands of municipal murals and extensive graffiti competing for attention on city walls. It is the result of a longstanding contestation between a vigorous tradition of transgressive street art and an ambitious municipal program aimed at controlling urban visual space by means of officially approved and sponsored public art. Philadelphia's role as a center of graffiti innovation is discussed as are the city's Anti-Graffiti Network and Mural Arts Program which aim to control graffiti by means of civic murals. Other efforts to beautify neighborhoods by means of public art as well as newer forms of illicit street art such as poster and stencil graffiti contributing to the graphic embellishment of public space are discussed.
Despite its reputation as one of the poorest and most violent large cities in the US, Philadelphia's streetscape is astonishingly varied and colorful. Graffiti murals along with many other kinds of transgressive wall art including tags, bombs, throw-ups, posters, stencils and stickers increasingly cover, with varying degrees of ambition and stylistic sophistication, the exposed spaces, walls and surfaces of the city. Moreover, the city is also home to an unparalleled number of civic murals as well as much other officially sponsored or sanctioned public wall art.

Indeed, in recent years more than three thousand municipal murals alone have been painted on walls, buildings and structures throughout the city. Enormous showpiece murals occupy prime locations in the downtown area and at 'gateway' locations to the city such as the airport, where the world's second largest mural "How Philly Moves" (a homage to dance in the city) runs along the entire façade of several multistory parking garages. Other large murals celebrate Philadelphia's contributions to the arts and architecture, comment on communalities that connect residents across generations and cultures, or mark important moments and figures in the civil rights movement and struggle to end slavery. For example, "Legacy" a 10,000 square foot mural at a downtown parking lot composed in part of a million hand laid glass tiles, shows a girl holding the 'flame of liberty' while wearing medals featuring Abraham Lincoln and Frederick Douglass as well as a 1838 abolitionist coin with the inscription "Am I not a woman and a sister."

Many murals, however, are located in less privileged parts of town, on the end walls of row homes or on walls exposed by fire, building collapse or demolition. Here myriad colorful panels stand sentinel over the vast swathes 

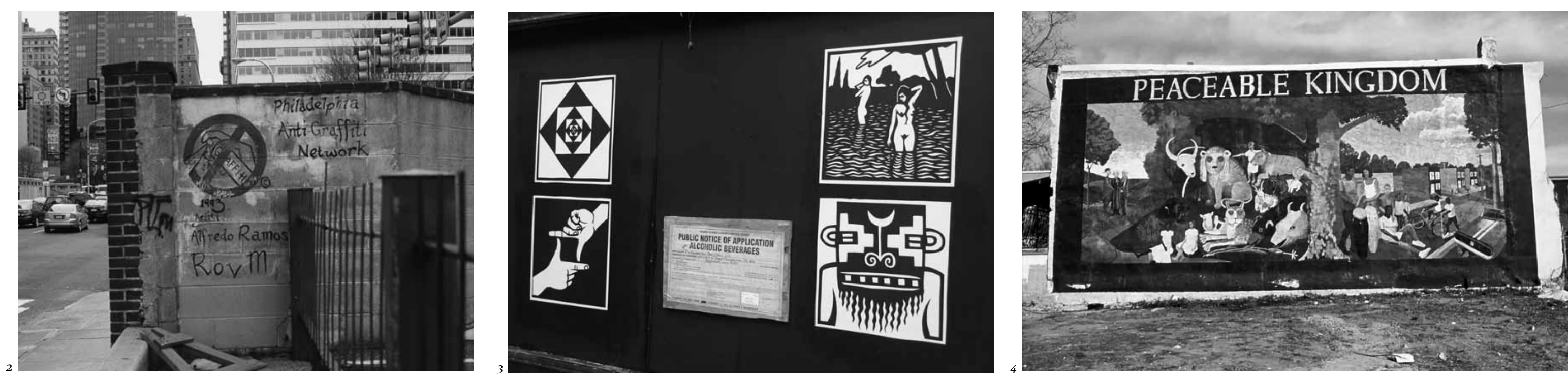
Figure 2
Stop Graffiti Philadelphia Anti-Graffit Network 1993, Alfredo Ramos) Recently re-exposed in the course ect, the crossed-out spray-paint can became the logo emblematic of the Anti-Graffiti Network

Figure 3 This abandoned building in an otherwise upscale neighborhood is a favored display site for posters of blight, dereliction and waste which surround them where they compete for attention among nearby graffiti walls, many memorials to those killed in the epidemic of violence which continues to plague the city. While other cities such as San Francisco, Chicago and Los Angeles have traditions of public murals, no other municipality matches Philadelphia's commitment to this kind of graphic outdoor art, surely making the City of Brotherly Love the mural capital of the United States, if not the world.

Philadelphia's visually striking streetscape emerges from a contestation, ongoing over many decades now, between a vigorous, irrepressible tradition of transgressive street art and an equally ambitious municipal program of control and domination of urban visual space by means of large scale public art. Indeed, alone among American cities, Philadelphia has adopted civic murals as a major part of its anti-graffiti strategy, seeking to displace, veil or domesticate graffiti by means of a variety of public art initiatives.

Philadelphia is now an acknowledged, if relatively poorly documented, center of original graffiti innovation (Gastman and Neelon, 2010; Haegele, 2001). As early as the 196os, urban disinvestment, middle-class flight to the suburbs, and race-based policies of discrimination were beginning to turn previously stable, but poor, working class inner-city districts of the city into zones of extensive blight and dereliction, fertile ground, as it turned out, for the emergence of urban youth gangs who proceeded to mark territory with a blizzard of tags, scribbles and other hieroglyphs. However, gang membership and the rituals of territoriality did not appeal to all disadvantaged urban youth; many gravitated to other kinds of wall writing such as tagging which offered more opportunity for individual aggrandizement as well as the freedom to move beyond the neighborhood and mark the city independent of gang turf (Phillips, 1999; Ley and Cybriwsky, 1974)

Indeed, many of today's familiar graffiti styles have their origins in mid-196os Philadelphia when legendary graffiti kings such as CORNBREAD (Darryl McCray) and KOOL KLEPTO KIDD (Bobby Kidd) established reputations by tagging widely in North and West Philadelphia respectively and, as legend has it, by "getting up" on police cars, elephants at the zoo, and even the Jackson Five's plane at the airport. However, as more and more people got involved with graffiti, CORNBREAD and others had to develop more creative lettering styles, adding embellishments such as crowns, hats and dollar signs to their tags in order to stand out from the crowd. According to KIDD the idea was "to get a little fancy, but you don't want to go overboard" (after all speed of execution was essential to avoid apprehension and arrest) (Gastman and Neelon, 2010:50). Since status derived from the visibility of work produced as
Figure 4
Peaceable Kingdom (Mural Arts Program 2001, Cho les A. Hankin). Incorporating mous $19^{\text {th }}$ century painting “Peaceable Kingdom" (of which he painted many versions between 1820 and his death in 1849), this mural offers an equally tranquil and harmonious vision of the local community, one however in reality beset with poverty, drugs descendant of Edward Hicks 

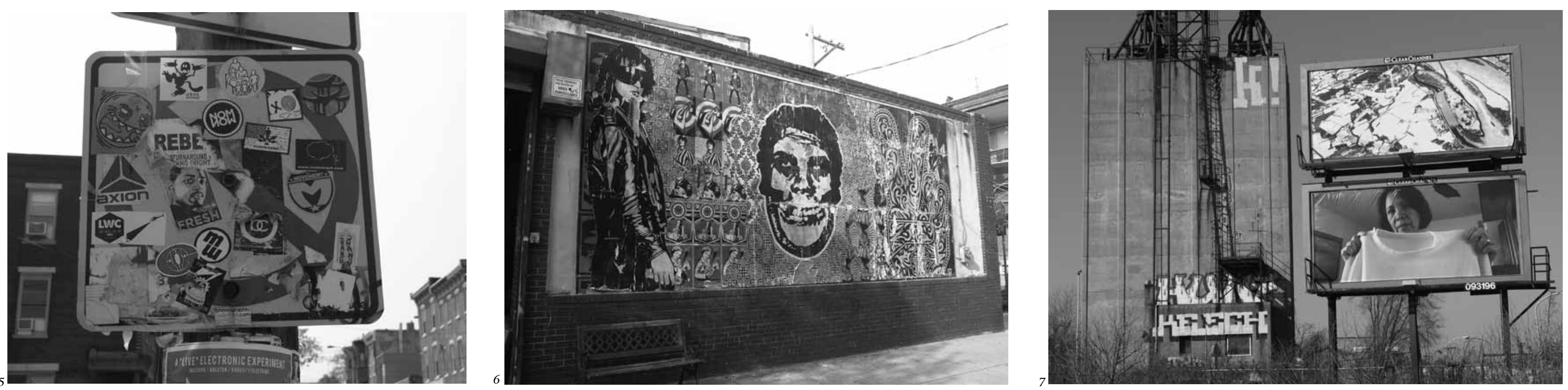

Figure 5
A blizzard of commercial and
non-commercial stickers covers a municipal street sign in the rapidly gentrifying Northern

well as its quantity, wall writers often competed to "get up" in dangerous locations including on abutments and bridges along highway and rail corridors

Philadelphia styles traveled quickly to New York where they were instrumental in shaping graffiti conventions emerging there. As one New York writer acknowledged "the kind of writing that is on our walls-highlighting names and egosbegan in Philadelphia" (Gastman and Neelon, 2010:52). By the early 1970 wall writing had blossomed into what became called hip hop graffiti ("New York style" or "subway art") characterized by balloon lettering, calligraphic extravaganzas, and ever more elaborate spray painted masterpieces, including the epitome of "top to bottom" subway car decoration. The style returned to Philadelphia and spread quickly to other US cities including Los Angeles, Chicago and other major metropolitan areas. Over time hip hop's transcendental aesthetic qualities, lack of overt politics, and commercial friendly cartoon style helped it travel far from its origins in the slums and barrios of America's cities. Spread through magazines, digital photography shared via the Internet, travel and music, hip hop graffiti became a global phenomenon as well as international youth subculture and has been the dominant style for much illicit wall art in Europe, Latin America and elsewhere.

By the 1970s the explosion of graffiti, tagging and wall writing had transformed Philadelphia into one of the most visually-blighted city in the world. Officials claimed graffiti decreased property values, drove away business, discouraged tourism and redevelopment and generally demoralized and intimidated residents. The city's transit authority was already spending over a million dollars a year to clean trains, buses and subway cars. However, rather than simply pursue an aggressive policy of graffiti removal coupled with prosecution of offenders in the courts (the norm in most cities), Philadelphia also sought to deter graffiti by covering walls that might otherwise be appropriated by graffitists with equally large and colorful, but officially sponsored and approved, community murals.

In 1984 the city established the Philadelphia Anti-Graffiti Network (PAGN), a program designed to clean up graffiti on walls as well as domesticate and reeducate graffiti artists by providing them with socially useful training in the arts, even the prospect of paid employment. In exchange for legal amnesty, wall writers were expected to give up graffiti and contribute to the clean-up of walls they had defaced. Observing that graffiti murals-- especially those commemorating homeboys and others cut down by street violence--were themselves rarely defaced, the PAGN established a mural painting program in which offenders were also expected to create legitimate neighborhood murals to compete with, and hopefully displace, unofficial murals (Rice, 1999).
Figure 7 Three Mile Island and Nila Holding Shirt (Zoe Strauss Billboard Project, 2012). Two of the more featuring enormous blow the city tographs by Zoe Strauss as part of her exhibition, Ten Years, at the Philadelphia Museum of Art 


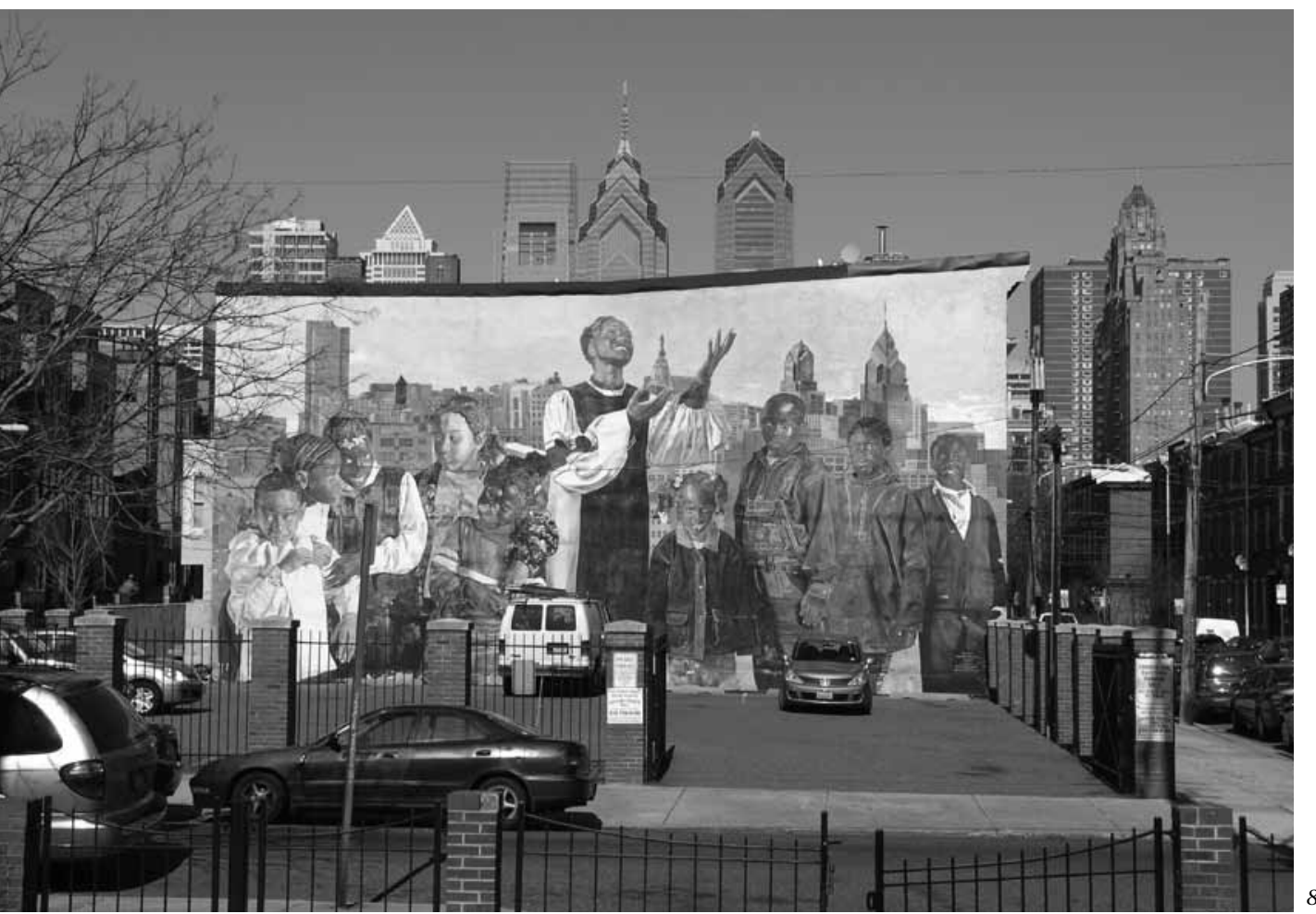

Figure 8 Children of Philadelphia (Mural Arts Program 20oo, Burton
Dodge). In this dramatic mural at the edge of downtown, the mural's painted city background reflects and merges with the real skyline of the city behind it.
Naturally the murals sponsored by the PAGN avoided the styles and subject matter of traditional graffiti walls ("wildstyle" 'pieces, glorification of violence, conspicuous consumption) in favor of themes drawn from AfricanAmerican history or figurative depictions of tranquil rural landscapes. However, since many graffitists co-opted into the PAGN program lacked the skill or training to create successful wall-sized murals, many early murals had a certain naïve, folk art quality to them. But today where these survive, their quirky charm is often a welcome relief from the now relentless graphic sophistication and technical perfection of more recently produced murals.

Not surprisingly, the Anti-Graffiti Network essentially split the graffiti underground into those who looked favorably on the chance to perhaps get a job and receive an art education, and those holdouts who, revering a more hostile, confrontational relationship to authority continued to cover city walls with tags, "throw-ups," and "pieces". However, in 1996 the city dismantled the PAGN and set
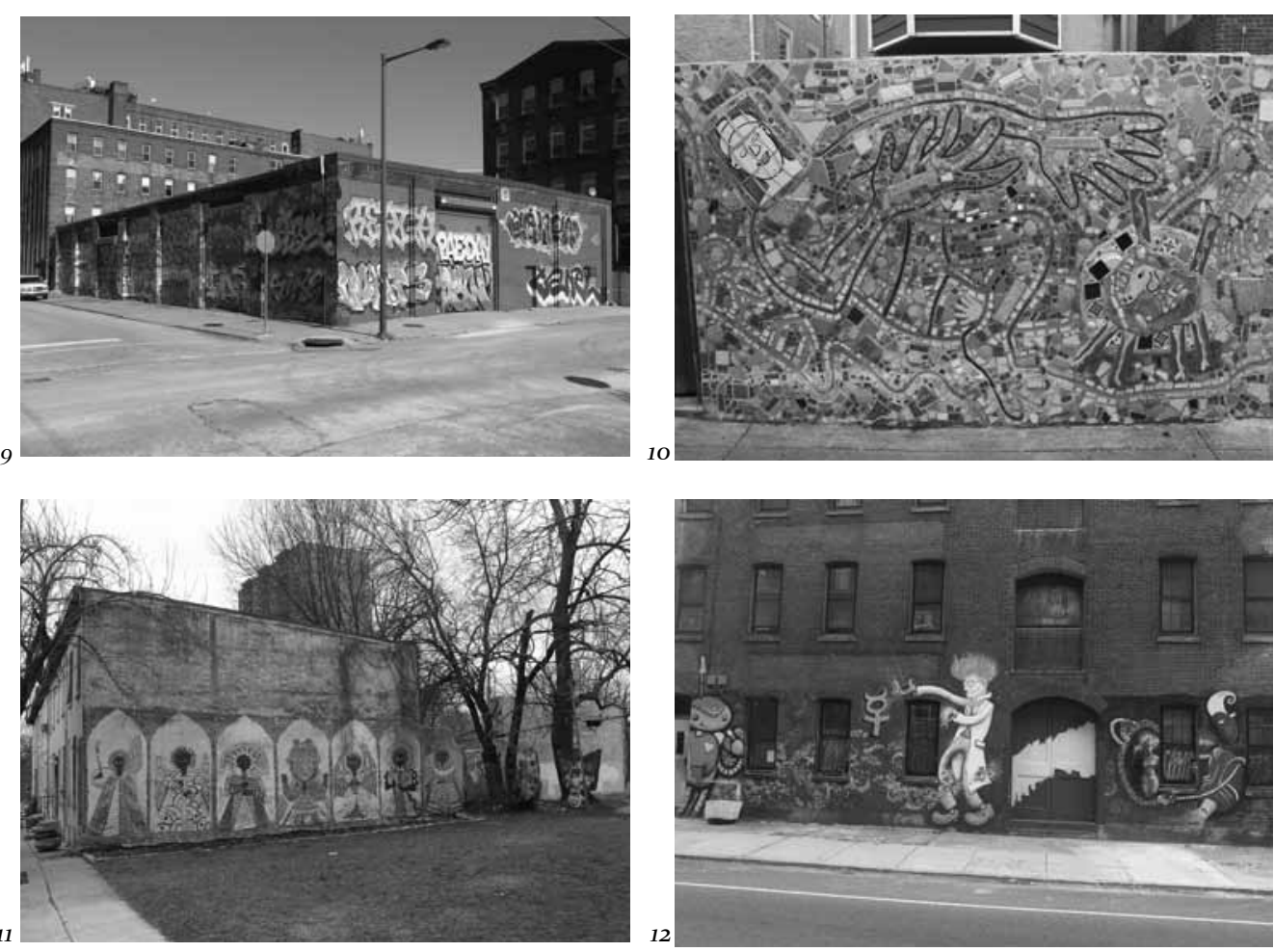

up new programs to manage and regulate visual aspects of public space. Responsibility for graffiti removal and cleanup was transferred to other city agencies which embarked on a vigorous program of graffiti abatement. The PAGN's muralpainting and educational functions were transferred to a new Mural Arts Program (MAP) which under the energetic leadership of its director, Jane Golden, one of the world's most vocal and enthusiastic proponents of community murals (previously she had been director of PAGN's mural program) has grown into what is perhaps the most active public art agency in the world.

Focusing almost exclusively on the creation of neighborhood murals rather than the earlier mission of domesticating graffitists, MAP's philosophy has broadened to emphasize the role of art in community development and education. For MAP, public art acts in the service of the community by serving as "a tool for change and consensusbuilding." Installing a mural in a community, it claims, can provide a positive forum where neighbors come together to
Figure 9 An elaborate "back to back" gra-

Figure 10

Mosaic Wall by Isaiah Zagar

Figure 11

Angel Alley, Village of Arts and Humanities

Figure 12
Cartoon-style art graffiti covers the front of a warehouse converPhiladelphia ted into loft apartments in North 

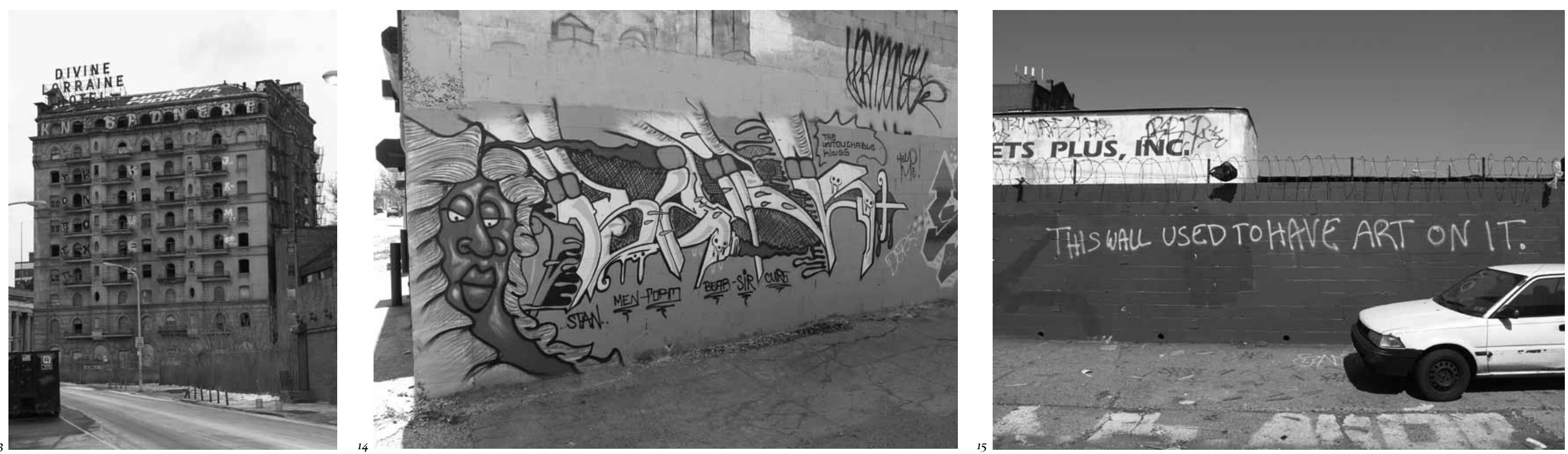

Figure 13
Divine Lorraine Hotel. Built in the late $19^{\text {th }}$ century as apartments for Philadelphia's webuilding was acquired in 1948 by Father Divine, leader of the Universal Peace Mission Movement. Renamed the Divine Lorraine Hotel, it was the first hotel of its kind in the United States to abandoned, graffiti bombers are attracted to its upper floors

work out differences and define common goals. Moreover, by helping young people to explore their creative potential and develop their artistic skills, MAP's various youth educational programs enhance self-esteem and eventual employment potential (Golden, Rice and Kinney, 2002; Rice, 2000).

For the most part MAP murals feature popular, noncontroversial and didactic themes executed in a large-scale, colorful and representational format (hardly surprising since many are funded by corporations and foundations). Community history and ethnic origins are popular themes, as are idealized landscapes depicting the changing seasons, rich agricultural vistas, or lush tropical scenes, often with waterfalls. Celebrities, entertainers, politicians and sports figures (especially those with a Philadelphia connection) are frequently the subject of larger-than-life wall portraits; other portrait murals celebrate ordinary people as heroes as well as commemorate police, firemen and other officials killed in the line of duty. Many promote the virtues of vaccination programs, literacy, tolerance, harmony, and peace. More recently, murals have begun to address the impact of crime, incarceration, violence and homelessness on individuals and the community. A few, including one by Keith Haring, are what might be called 'art' murals, eager to contribute an aesthetic gesture rather than make a didactic statement.

Organizations other than the Mural Arts Program, as well as individual artists, also promote public art as a way to stabilize and beautify neighborhoods, thus contribute to Philadelphia's art-saturated streetscape. One of the most active organizations in this regard is the Village of Arts and Humanities, established by Lily Yeh in 1986 in one of the city's most blighted neighborhoods (Hammett, 1999). According to founder Yeh, "there were a lot of vacant lots and a lot of empty buildings. I just began to transform dead space into a living space with energy and light. I built the village as one living sculpture"(Rice, 2000:10). Using the skills, energies, and resources of local residents rather than relying on imported artistic talent, the Village has transformed vacant spaces and exposed walls over several blocks in the heart of the city's 'badlands' with primitive-style wall mosaics, sculptures, and architectural constructions. Rejecting MAP's literal and representational style, the Village aesthetic favors smaller works which celebrate folk forms and motifs worked up in flat simple colors, thus promoting a public art that is more decorative than didactic.
Figure 14
A graffiti wall in North Philadelphia

Figure 15

"This Wall Used To Have Art On It." Site of the famous permis-

North Philadelphia 
FUOCO, D. A. Art for everyone. Philadelphia Inquirer. August 7, H-1, H-8, 2011.

GASTMAN, R. and NEELON, C. The history of American graffiti. New York: Harper Design, 2010.

GOLDEN, J., Rice, R. and YANT KINNEY, M. Philadelphia murals and the stories they tell. Philadelphia: Temple University Press, 2002.

HAEGELE, K. Kings of Philly. Philadelphia Weekly. October 24, p. 16-21, 2001

HAMMETT, K. The Village of Arts and Humanities. Designer/builder. January, p. 25-31, 1999.

LEY, D. and CYBRIWSKY, R. Urban graffiti as territorial markers. Annals of the Association of American Geographers. Vol. 64, December, p. 491-505, 1974

PHILLIPS, S. A. Wallbangin': graffiti and gangs in LA. Chicago: University of Chicago Press, 1999.

RICE, R. Brief history of Philadelphia wall art. In Philadelphia murals: 1970-200o. Fleisher Art Memorial: Philadelphia, 2000, p. 5-10.

RICE, R. Art as civic biography: Philadelphia murals project. New Art Examiner. April, p. 18-22, 1999.

VALDEZ, A. Public images: colorful stencils are popping up all over Philly. Philadelphia Weekly. September 22-28, p. 1719, 2004.

WALLON, M. Graffiti's cozy, feminist side. New York Times. May 19, E-1, E-2, 2011

ZAGAR, I. and HALKIN, B. Philadelphia's magic garden: the art of Isaiah Zagar. Philadelphia: Open Eyes Press, 1999.

Recebido em: 02/03/12

Aceito em: 04/12/12
JAMES DICKINSON

dickinson@rider.edu

É professor do Departamento de Sociologia da Universidade de Rider em Lawrenceville, New Jersey, USA. Tem escrito sobre monumentos e ruínas urbanas, explorando o modo como os ambientes construídos das velhas cidades industriais americanas expressam mudança, conflito e desigualdades. O seu trabalho atual explora as dinâmicas da cultura visual urbana e o papel da fotografia na construção de narrativas sobre as paisagens modernas e pós-modernas. 